\title{
Ethnicity coding revisited: right-wing parties as catalysts for mobilization against immigrant welfare rights
}

Article

Accepted Version

Arndt, C. and Thomsen, J. P. F. (2019) Ethnicity coding revisited: right-wing parties as catalysts for mobilization against immigrant welfare rights. Scandinavian Political Studies, 42 (2). pp. 93-117. ISSN 1467-9477 doi: https://doi.org/10.1111/1467-9477.12145 Available at https://centaur.reading.ac.uk/84415/

It is advisable to refer to the publisher's version if you intend to cite from the work. See Guidance on citing.

To link to this article DOI: http://dx.doi.org/10.1111/1467-9477.12145

Publisher: Wiley

All outputs in CentAUR are protected by Intellectual Property Rights law, including copyright law. Copyright and IPR is retained by the creators or other copyright holders. Terms and conditions for use of this material are defined in the End User Agreement.

www.reading.ac.uk/centaur 
Central Archive at the University of Reading

Reading's research outputs online 


\title{
Ethnicity Coding Revisited: Right-Wing Parties as Catalysts for Mobilization Against Immigrant Welfare Rights
}

\author{
Abstract: \\ Ethnicity coding means that negative views of ethnic minority members spur opposition \\ to specific welfare programs. To advance knowledge of the influence of political parties \\ on ethnicity coding, we apply a dynamic approach. Longitudinal analyses show that: a) \\ because political parties persistently frame state pensions as benefitting native majority \\ members, a perceived ethnic threat increases support for this welfare scheme, and b) \\ perceived ethnic threat reduces support for social assistance when political parties frame \\ it as favoring immigrants. Extending these findings, we show that opposition to \\ immigrant welfare rights prompts electoral realignment, as left-wing voters increasingly \\ switch to right-wing parties. More generally, political parties are capable of stimulating \\ opposition to parts of the welfare state, including electoral mobilization against \\ immigrant welfare rights. We utilize unusually rich mass-level survey data from \\ Denmark, covering a 25-year period (1990-2015). The broader implications of our \\ findings for theories of ethnicity coding, political elite persuasion, and welfare state \\ development are discussed in the conclusion.
}




\section{Introduction}

Immigrants and refugees increasingly disperse beyond the usual gateway nations. This makes it urgent to examine the dynamics of so-called ethnicity coding of welfare among richer nations. A welfare policy is ethnicity coded if native majority members oppose it because they believe that ethnic minority members are exploiting it. Previous studies of primarily Anglo-Saxon nations have found empirical support for the ethnicity-coding hypothesis (Alesina \& Glaeser 2004; Ford 2016; Gilens 1996; Harell, Soroka \& Ladner 2014; Larsen 2011; Winter 2006).

However, how ethnicity coding emerges remains a puzzle outside the U.S. context. Previous studies have found an inverse relationship between negative views on immigrants and support for social assistance in Denmark, Britain, Norway, and Sweden (Bay, Finseraas \& Pedersen 2013; Ford 2016; Hjorth 2016; Larsen 2011). Despite their undeniable merits, however, these studies were not longitudinal, nor did they examine the dynamics of ethnicity coding across different welfare schemes (also Eger 2010; Schmidt \& Spies 2014).

Moreover, it remains unexamined whether another indicator of ethnicity coding opposition to immigrant welfare rights - has provoked electoral realignment in generous welfare states. Some studies have focused narrowly on how opposition to immigrant welfare rights increases support for radical right parties while ignoring broader realignment processes (de Koster, Achterberg \& van der Waal 2012; Eger \& Valdez 2015). This means that we know remarkably little about the evolution of ethnicity coding and even less about its long-term electoral importance (see e.g., Bay, Finseraas \& 
Pedersen 2013; Brady \& Finnigan 2014; Eger 2010; Ford 2016; Larsen 2011; TaylorGooby 2005).

In view of these limitations, we expand previous research by examining the longterm impact of ethnicity coding on welfare support and vote choice in Denmark - a crucial case because of its exceptionally strong tradition of social solidarity (across income differentials) and history of ethnic homogeneity. Indeed, according to Alesina and Glaeser's (2004) famous ethnic fragmentation thesis, ethnicity coding should not occur in such a nation. Treating Denmark as a least-likely test case, however, and inspired by Winter's (2006) conjecture, our theory is that political party frames encourage ethnicity coding. We are the first to introduce a top-down approach to the emergence of ethnicity coding in Scandinavia.

To advance knowledge of ethnicity coding from a top-down perspective, we examine aspects of Danish welfare over a 25-year period. Consistent with Winter (2006), we do not expect all welfare policies to be ethnicity coded. Thus, unlike some previous studies (Alesina \& Glaeser 2004; Bay, Finseraas \& Pedersen 2013; Eger 2010; Larsen 2011), we hypothesize $\left(\mathrm{H}_{1}\right)$ that perceived ethnic threat increases support for generous old age pensions as they are politically framed as benefitting the native majority group (Winter 2006). In contrast, we hypothesize $\left(\mathrm{H}_{2}\right)$ that perceived ethnic threat reduces support for generous social assistance when politically framed as benefitting immigrants. We also expand previous research (Bay, Finseraas \& Pedersen 2013; de Koster, Achterberg \& van der Waal 2012: Eger 2010; Gilens 1996; Larsen 2011) by hypothesizing $\left(\mathrm{H}_{3}\right)$ that voters wanting to restrict immigrant welfare rights increasingly support right-wing parties when they make the welfare costs of immigration a political 
issue. The three hypotheses are examined using high-quality national election surveys covering the period 1990-2015, including more than 15,000 individuals. Empirical analyses support our hypotheses.

\section{Ethnic Threat as a Potential Influence on Welfare Attitudes}

A key component of ethnicity coding is perceived ethnic out-group threat, which refers to fears of harmful cultural or economic consequences (Sniderman \& Hagendoorn 2007). According to this definition, perceived ethnic threat must relate to mass-level 'negativity bias'; the ordinary citizen is instinctively more attentive to negative than positive stories (Soroka 2006). Negativity bias in turn motivates thinking about costs in settings where immigrants are disproportionately depending on social assistance. The average citizen will be informed about such economic and social realities, primarily because right-wing political discourse often accentuates the burdens of (non-Western) immigration (Brader, Valentino \& Suhay 2008). ${ }^{1}$

To delve deeper into the political cognition of ethnicity coding, we expand on Winter's (2006) 'group implication' concept, which refers to the heuristics that associate welfare schemes with specific stereotypes - such as 'the hard-working native majority member', or 'the lazy ethnic minority member' (Gilens 1996). Accordingly, some welfare policies (e.g., benefits to the elderly) have positive associations, as they assist a hard-working group (Winter 2006). In turn, this welfare scheme is coded in terms of the ethnicity of the native majority group and associates with positive stereotyping. Others, such as means-tested cash transfers to the unemployed, may be associated with immigrants who are feared because of their culture or work ethic. Naturally, this welfare 
scheme has an ethnicity coding linked to negative stereotyping of immigrants.

Accordingly, among native majority members who feel threatened by immigration, seniors may appear to be deserving, whereas immigrants on means-tested benefits appear undeserving of government help. ${ }^{2}$ Even so, ethnicity coding is hardly reducible to such individual-level cognition processes.

\section{Right-Wing Parties Offer Threat-Welfare Frames}

Indeed, the immigration-welfare nexus is difficult to understand for the average citizen, implying that strong, bottom-up claims about the automaticity of threat-induced reactions toward immigrants should be met with skepticism. In fact, numerous studies have consistently concluded that the average citizen is ill-informed about political issues and inattentive to them (e.g., Luskin \& Bullock 2011; Sniderman \& Hagendoorn 2007).

Because of their limited cognitive capacity, ordinary citizens require guidance to enable them to form opinions on specific issues. We draw on Zaller's (1992: 6) assertion that opinions on specific political issues originate from 'a marriage of information and predispositions'. Political parties offer simplified and accessible information to the masslevel public. By framing some 'social realities' rather than others, political parties make political issues salient among the mass public.

In addition to the salience effect, the specific message of political party frames also matters (Hurwitz \& Peffley 2005). If right-wing political parties frame immigrants as taking advantage of social assistance, this message may mobilize acceptance among those who are predisposed to perceive immigration as a threat - rather than among those who see immigration as harmless. Consequently, under such circumstances, those high in 
perceived ethnic threat begin to oppose social assistance. From this top-down perspective on public opinion formation, it follows that average citizens are unlikely to translate their predispositions (i.e., perceived threat) into negative opinions on specific welfareimmigration issues if they remain unnoticed among right-wing political elites.

Building on the rationale of this top-down perspective, we hypothesize $\left(\mathrm{H}_{1}\right)$ that perceived ethnic threat increases support for spending on welfare schemes benefitting native majority members - referring to state pensions in particular. We expect this relationship to be positive - and perhaps increasingly so - because political parties across the ideological divide most likely frame state pension as a good that native majority members deserve because of their hard work (Winter 2006). In contrast, we hypothesize $\left(\mathrm{H}_{2}\right)$ that perceived ethnic threat among native majority members relates negatively to support for spending on social assistance. We expect that this relationship emerges and becomes negative when right-wing political parties begin framing immigration as a welfare burden.

\section{Opposition to Immigrant Welfare Rights Influences Vote Choice}

In its present form, our ethnicity coding argument has the same limitation as some previous studies (e.g., Bay, Finseraas \& Pedersen 2013; Eger 2010; Ford 2016; Larsen 2011). They use non-longitudinal analyses to show how negative views of immigrants (or greater ethnic diversity) relate to opposition to social assistance. Despite their undeniable merits, these findings may not reveal the full capacity of ethnicity coding. To provide a clearer theoretical statement than previous research, it is necessary to differentiate between weaker and stronger cases of ethnicity coding. A weak case occurs when 
negative views of ethnic minority members reduce support for some welfare policies. Yet ethnicity coding is not only about the resentment-welfare relationship. It is also about the readiness to deny ethnic minority groups certain social rights. Thus, a stronger case of ethnicity coding occurs when opposition to immigrant welfare rights influences vote choice (and ultimately government policy). The differentiating factor is the extent to which ethnicity causes political mobilization.

European research on the mobilization issue has had a rather narrow perspective. De Koster, Achterberg \& van der Waal (2012) found that welfare chauvinism fosters support for radical right parties in Holland. Similarly, Eger \& Valdez (2015) concluded in cross-national study that radical right parties attract voters who wish to restrict social benefit rights to native majority members. None of these studies, however, examined how opposition to immigrant welfare rights affects broader processes of dealignment and realignment. In effect, we need to show that political mobilization over immigrant welfare rights also characterizes the Danish case. Even more, we hypothesize $\left(\mathrm{H}_{3}\right)$ that opposition to immigrant welfare rights increases the likelihood of some voters to switch from left-wing to right-wing political parties. Consistent with Hillygus \& Shields (2008), immigrant welfare rights may qualify as a wedge issue making right-wing parties capable of attracting some portion of the left-wing parties' supporters.

\section{Case Selection, Data, and Measures}

Unlike the USA, Denmark is a conservative case potentially biased against the occurrence of ethnicity coding. Its generous welfare state builds on social solidarity, it has historically been an exceptionally homogenous nation (i.e., there is no longstanding 
interethnic conflict), and it still has a comparatively low share of foreign-born residents (Jønsson \& Petersen 2013). ${ }^{3}$ To examine our three hypotheses, we utilize the Danish National Election Studies (henceforth: DNES). Eight different years of the DNES were employed (see the online appendix for details). The analyses below are based on a pooled sample of these surveys.

The DNES include various (identical) measures of opinion on welfare spending, views on immigrant welfare rights, and perceived ethnic threat. Specifically, we measure perceived ethnic threat using the following item: 'Immigration is a serious threat to our national distinctiveness' (response categories: $1=$ agree completely, $2=$ agree partly, $3=$ neither/nor, $4=$ disagree partly, $5=$ disagree completely). This item was recoded, greater values indicating higher perceived ethnic threat. ${ }^{4}$ Although different from previous studies (see Eger 2010; Gilens 1996; Winter 2006), we believe that the measure has distinct qualities as it definitely taps negative reactions toward and ethnic out-group.

To measure opinion on welfare spending, we use a 3-point scale: 'Do you think that the state spends too much, the right amount, or too little money on [policy area]'. To ease interpretation, we recoded this measure: 'too much' $=-1$, 'right amount' $=0$, and 'too little' $=1$. To specify the policy area of the stem, we treat the so-called people's pension (i.e., the state pension) as a social security scheme favoring native majority members, and social assistance as a scheme that disproportionally favors immigrants. ${ }^{5}$

[Figure 1 about here] 
To justify that the self-reported expenditure measures suit our purpose, Figure 1 displays the share of recipients of the state pension and social assistance by ethnic background during the period 1997-2015. Those benefitting from the people's pension are almost exclusively native majority members, totaling more than 95 percent of the recipients across the entire period. The share of non-Western immigrants among people's pension recipients is persistently below three percent and considerably below the share of non-Western immigrants measured as percentage of the total population. Consequently, the people's pension appears to be a welfare scheme that almost exclusively favors native majority members. In contrast, while less than 10 percent of the population is of nonWestern descent, non-Western immigrants make up 25-30 percent of all social assistance recipients, offering a clear case of disproportionate representation.

In sum, two key observations deserve emphasis. First, the public pension scheme disproportionally aids the native majority group, whereas social assistance disproportionally helps (non-Western) immigrants. Thus, disproportionate immigrant representation is a social fact that may serve purposes of political manipulation. Second, Figure 1 also shows that the disproportionate representation of immigrants among social assistance recipients is a constant feature during the period 1997-2015. In fact, it has been a constant feature since the 1980s (not shown). Obviously, this means that actual immigrant overrepresentation cannot itself account for any observed variability in masslevel ethnicity coding.

Utilizing this background material, our first analytical step is to examine the impact of perceived ethnic threat on attitudes toward the people's pension and social assistance in the period 1990-2015. The specific statistical models include numerous controls. First, 
we use an ordinal item measuring opposition to 'big government' with the following wording: 'A says: "Social reforms in this country have gone too far and that people should become more independent of social security". B says: "The social reforms that have been implemented in our country should at least be preserved as they are now"" (response categories recoded into $1=$ agree with $\mathrm{A}, 2=$ agree with $\mathrm{B}$, or $3=$ neither agree with A nor B). Next, additional controls were: gender, age, education, social class, labor market status, union membership, party identification, support for egalitarianism, and left-right self-placement (see the online appendix for details). ${ }^{6}$

As a next analytical step, we examine the electoral implications of ethnicity coding. At this stage, the independent variable has the following wording: 'Refugees and immigrants should enjoy the same right to welfare benefits as Danes, even if they do not have Danish citizenship' (response categories were: $1=$ totally agree, 2 = partly agree, 3 $=$ neither/nor, $4=$ partly disagree, and $5=$ totally disagree). The dependent variable is vote choice and with a particular focus on the two largest right-wing parties (the Liberals and the Danish People's Party), since they are likely to benefit from diminishing support for immigrant welfare rights. ${ }^{7}$ The Social Democrats and the leftist Socialist People's Party are also of interest, as they are likely to lose voters who wish to restrict immigrant welfare rights. The models also include the remaining parties, and the online appendix (Table E1 and Figure E1) reports the results related to them. ${ }^{8}$ The online appendix offers additional details on key measures (Tables A1-A3). Finally, because of the nature of the dependent measure, we apply an ordered logit approach (unless otherwise stated).

\section{Party Messages about the Immigration-Welfare Association}


Recall that the top-down perspective claims that political parties influence the mass-level by framing specific issues, which in turn help citizens to establish the policy implications of their own predispositions. Fortunately, the agenda-setting activities of the Danish political parties during the period 1990-2015 have been systematically examined and these follow a distinct agenda-setting pattern with a decisive turning point. We show this in Figure 2 by summating the parties' positions on multiculturalism, internationalism and the preservation of national way of life from the Comparative Manifesto Project data as a measure of immigration policy positions over time. Positive (negative) values indicate conservative (liberal) positions on immigration (see also source of Figure 2 on calculation details).

[Figure 2 about here]

Non-Western immigration to Denmark began in the early 1970s, but at that time immigration was almost absent from the political party manifestos as shown in Figure 2. Green-Pedersen (2011) also showed that immigration was almost absent from parliamentary debate in the period 1970-80. Political observers believed that the traditional right-wing parties would opt for a stronger focus on immigration issues in the 1980s. However, they missed that the right-wing governments did not have a parliamentary majority during the 1980s, instead highly dependent on support from the small centrist party (the Radical Liberals). This party vetoed stricter immigration policies, meaning that the traditional right-wing parties had to treat immigration as a 'non-issue' to 
remain in power. Figure 2 confirms this inactivity of the traditional right-wing parties during the 1980 s.

The creation of a new party in 1995 - the Danish People's Party (DPP) - altered the political-party landscape. The DPP was and remains strongly opposed to non-Western immigration. Soon, the DPP offered vital support to successive right-wing governments in the period 2001-18. As illustrated in Figure 2, this has meant that the traditional rightwing parties have placed immigration center-stage since the late 1990s (Bale 2003; Green-Pedersen 2011).

Because of important changes to the party-political system, immigration issues became considerably more salient at the elite level in the late 1990s. Yet very few studies have examined the dominant party frames since the mid-1990s. Figure 2 shows how the Liberals and DPP started framing immigration negatively in the last half of the 1990s, whereas the left-of-center political parties defended a positive framing. More specifically, a recurring message from the traditional right-wing parties and the DPP was that the number of incoming foreigners from Muslim countries should be reduced. Right-wing politicians repeatedly proclaimed that the number of (non-Western) foreigners vastly exceeded the inclusive capacity of the labor market and local communities (Brochmann \& Hagelund 2011).

Ultimately, and according to these parties, excessive non-Western immigration and refugee inflows represent a threat to national welfare. Indeed, right-wing governments have initiated unprecedented cuts to social assistance targeting incoming foreigners to make the nation less attractive (Grødem 2017). Since 2001, right-wing prime ministers and ministers of finance have made repeated declarations along the lines 
of, 'immigration is only advantageous to Denmark if immigrants get into permanent jobs'. Similarly, the DPP has frequently emphasized that asylum seekers only come to Denmark because of the country's generous social assistance scheme. Obviously, these official statements play on a group-centric 'threat frame' that includes symbolic reference to an allegedly poor work ethic among immigrants/refugees and to the limits of welfare generosity among hard-working native majority members.

Right-wing parties, including the DPP, have not defended an anti-welfare policy. Rather, the message during the period 2001-17 was that revenues should be allocated to what these parties have re-labelled 'core welfare' areas, such as state pension, eldercare, and health. Most remarkably, right-wing parties have increasingly argued that public spending should be more generous in these welfare areas because they are vital for the nation and because the average citizen has earned these services (Arndt 2016).

Indeed, the state pension scheme has been an almost apolitical issue since its introduction in the 1950s. Certainly, the right-wing parties have argued over the last three decades that welfare cuts were needed to protect generous state pensions. Right-wing parties have thus framed the pension area in positive terms - unlike their message regarding social assistance. Right-wing parties rhetorically associate specific parts of the welfare state with immigrants and other parts with the native majority group.

\section{Perceived Ethnic Threat and Opinions about Two Welfare Schemes}

[Table 1 about here] 
In our modelling, election years serve as moderators, as they can identify the extent to which the two main right-wing parties reposition on immigration issues. ${ }^{9}$ Table 1 shows the effect of perceived ethnic threat on support for the people's pension over time. Except for Model 1, all models include an interaction term (perceived ethnic threat $\times$ election year) meant to measure the extent to which the impact of perceived ethnic threat on support for the people's pension strengthens over time. The base model M1 shows that perceived ethnic threat relates significantly and positively to support for more spending on the people's pension. The interaction terms in Models 2-5 inform that the impact of perceived ethnic threat on support for spending on the people's pension strengthens across time regardless of whether egalitarianism, labor market status, or party identification are included as additional controls. Because logit interaction coefficients have no intuitive meaning (Ai and Norton 2003), Figure 3 shows the marginal effect of perceived ethnic threat on positions on spending for the people's pension over various years. ${ }^{10}$

[Figure 3 about here]

The positive impact of perceived ethnic threat on supporting greater spending on the people's pension clearly increases from one election year to the next. Indeed, the probability of agreeing that the pension is 'too low' increases at every election among voters perceiving immigration as a threat; and the difference in predicted probabilities between 1990 and 2015 is significant at $\mathrm{p}<.05$ (two-tailed) for both the baseline specification (M2) and the full model (M5). The opposite pattern relates to the response 
category 'fair'. Substantially, this finding suggests that perceived ethnic threat reduces the probability of perceiving state pension spending as fair at every election. Finally, perceived ethnic threat also reduces the likelihood of viewing the people's pension as 'too generous' throughout the period, although this effect is trivial. ${ }^{11}$ Consistent with our hypothesis $\left(\mathrm{H}_{1}\right)$, then, the results suggest that perceived ethnic threat increases support for more spending on the state pension - a welfare scheme that disproportionally benefits native majority members. Recall that right-wing political parties have consistently framed this scheme as generous financial help to hard-working, deserving citizens.

Table 2 shows an ordinal logit model in which social assistance serves as the dependent measure, and the related marginal effects reported in Figure 4 reveal an entirely different pattern. In the baseline model (M1) in Table 2, it appears as though perceived ethnic threat reduces support for spending on social assistance substantially. The more immigration is perceived as a threat, the less native majority members are willing to support a more generous social assistance scheme. The interaction terms in Models 2-5 suggest that the impact of perceived ethnic threat strengthens across the period, although it is only statistically significant at conventional levels in Model 5.

[Table 2 about here]

Again, we apply a marginal effects approach to ascertain the substantial magnitude of the findings. Figure 4 shows the marginal impact of perceived ethnic threat on support for social assistance spending across a 25 -year period. Pereceived ethnic threat increases the likelihood of preferring less spending on social assistance, and this effect is statistically 
significant across the entire period, although it strengthens only marginally. More specifically, a change of one unit on the perceived ethnic threat scale increases the likelihood of supporting lower social assistance spending by around three percentage points. As far as the the categories 'fair' and 'too low' are concerned, a one-unit increase on the perceived ethnic threat scale strengthens these two effects across time (i.e., across time, more of those who perceive immigration as a threat are more likely to report 'fair' and less likely to report 'too low'). Remarkably, in 1990, the marginal effect of perceived ethnic threat on viewing spending on social assistance as 'fair' is significantly below zero, whereas this effect turns non-significant in 2015; the difference in predicted probabilities between 1990 and 2015 is also significant at $\mathrm{p}<.05$ (two-tailed t-tests), and this applies for both the baseline and full models (M2 and M5). Moreover, the strong negative impact of perceived ethnic threat on viewing social assistance as 'too low' actually doubles over the entire period 1990-2015 (the difference in predicted probabilities across the period is statistically significant at $\mathrm{p}<0.1$ in the base model and $\mathrm{p}$ $<0.01$ in the full model).

[Figure 4 about here]

Consistent with our hypothesis $\left(\mathrm{H}_{2}\right)$, perceived ethnic threat reduces support for a more generous social assistance scheme. Equally consistent with the hypothesis, the negative impact of perceived ethnic threat on support for increased spending on social assistance strengthens, especially since the latter half of the 1990s. This sequential pattern suggests that the right-wing political parties' framing of the immigration-welfare link has 
been conducive to mass-level ethnicity coding. ${ }^{12}$ When referring to right-wing parties we mean The Liberals, The Conservatives, and the Danish People's Party.

Wright \& Bloemraad (2012) emphasize that the immigration debate in Europe primarily addresses Muslim immigrants. If true, this calls for a robustness check of the findings, as our dependent measure refers to 'immigration' in a general way. Accordingly, we reran the analysis with an alternative dependent measure of whether native majority members perceive Muslim countries as a threat to national security (exact wording: 'Muslim countries are a dangerous threat to Denmark's security'; response categories: 1 = disagree completely, 2 = disagree partly, $3=$ neither/nor, $4=$ agree partly, $5=$ agree completely). Although this variable taps into national security threats, it has the distinct quality of referring exclusively to Muslim countries; indeed, most non-Western immigrants and refugees in Denmark originate from Muslim countries. ${ }^{13}$

As a robustness check, Figure 5 shows the marginal impact of perceiving Muslim countries as a security threat on support for the people's pension and social assistance. The results are remarkably similar to those in Figures 3 and 4, and also stronger: Higher scores on perceived ethnic threat relates positively to support for increased state pension spending, whereas perceived ethnic threat relates negatively to support for increased spending on social assistance. Moreover, the effect of perceived Muslim threat becomes stronger over the course of the period, as right-wing political parties have defended the generosity of the state pension and framed immigrants as citizens who are not trying hard enough.

[Figure 5 about here] 
The robustness analysis lends additional support to the claim in $\mathrm{H}_{2}$. It is equally important to recall the results from Figure 1, showing that non-Western immigrants are disproportionately represented among social assistance recipients. The observed disproportionate representation of immigrants among social assistance recipients is a constant feature over several decades, whereas the association between perceived ethnic threat and opposition to spending on social assistance emerges and becomes stronger since around the late 1990s. Together, the two findings strongly suggest that disproportionate immigrant representation on social assistance cannot account for the variable impact of perceived ethnic threat on views of social assistance; however, the frames of the right-wing political parties certainly can.

As a final robustness check, we ran new analyses of additional spending schemes. Table D1 in the online appendix shows the results among which we address the schemes related to immigrants, education, and foreign aid. Unsurprisingly, Table D1 in the online appendix shows that perceived ethnic threat reduces support for increased spending on refugees and immigrants. More interestingly, perceived ethnic threat also reduces support for greater spending on education and foreign aid. In other spending areas, we cannot observe any significant changes over time (e.g., unemployment benefits and childcare). It is not possible to go into detail about how the right-wing parties have framed spending on immigration, education, and foreign aid over time, but we can offer some general evidence. Since the late 1990s, the right-wing parties have continuously emphasized that the inflow of foreigners is too costly; more recently, right-wing governments have started publishing their estimates of the exact costs of immigration. 
They have also addressed integration problems among (non-Western) immigrant children in primary school while defending parents' right to choose a private school for their children. Likewise, since the late 1990s, the right-wing parties have emphasized how foreign aid and the number of incoming immigrants are inseparable: When the inflow of foreigners increases, spending on foreign aid should be reduced accordingly (OECD 2016). ${ }^{14}$ In sum, ethnicity coding is not a consistent feature across a number of welfare schemes but it more or less follows - as the theory predicts - the threat-oriented frames offered by right-wing political parties. ${ }^{15}$

\section{Opposition to Immigrant Welfare Rights Stimulates Realignment}

Having shown that perceived ethnic threat among native majority members increasingly influences their views on social assistance to immigrants, we turn to the electoral implications of ethnicity coding. Is ethnicity coding a motivational impulse to partisan realignment? We also wish to expand our research question by focusing on native majority members' views on immigrant welfare rights more generally; or more precisely, whether opposition to immigrant welfare rights stimulates partisan realignment.

Consistent with our theoretical framework, we expect that native majority members who oppose universal immigrant welfare rights will increasingly align with the Liberals and the DPP, as these parties have introduced numerous restrictive immigration policy proposals since the mid-1990s. In contrast, the traditional guardian of existing welfare arrangements - the Social Democrats - mostly likely loses support among voters who no longer support universal welfare benefits because they believe that immigrants exploit them. The other left-wing parties are unlikely to be affected by ethnicity coding, 
as they do not attract many voters who deny some groups their full social rights (Thomsen 2006).

To justify that views on social assistance spending and immigrant welfare rights are intimately related, Table 3 cross-tabulates the two measures. Among native majority members who consider social assistance to be too generous, almost three-quarters of the respondents wish to restrict immigrant welfare rights. Similarly, among native majority members who consider social assistance too low, a slim majority (50.32 percent) believes that immigrants should enjoy the same welfare rights as everyone else. In other words, the new item addressing immigrant welfare rights is an indicator of ethnicity coding although it evidently expands the analysis by addressing the extent to which native majority members deny immigrants some of the core rights of democratic citizenship.

[Table 3 about here]

We ran a series of statistical models, which included vote choice as the dependent variable and an interaction term (immigrant welfare rights $\times$ election year) as the main predictor. We included numerous controls (gender, age, education, social class, union membership, attitudes toward big government, egalitarianism, and perceived ethnic threat). ${ }^{16}$ To ease interpretation, we show the marginal impact of restricting immigrant welfare rights on vote choice among four specific political parties over the period 19902015. First, we show the results of a baseline model that includes socio-demographics and 'big government' as controls. Subsequently, we show a full model in which egalitarianism and threat perceptions are also controlled (see Table E1 in the online 
appendix for the full models and detailed model specifications). We also assume that the 'big government' item taps welfare preferences and dissatisfaction with welfare cuts in general. Generating similar findings in both models would suggest that immigrant welfare rights have a strong influence on vote choice irrespective of general predispositions.

Figure 6 presents the marginal effects of views on immigrant welfare rights on vote choice generated by two models. The marginal effect identifies the impact of a onepoint increase on the immigrant welfare rights scale (1-5) on vote choice in all of the elections. Both specifications show a positive effect of restricting immigrant welfare rights on voting for the DPP, which also increases over time. The base-line model (on the left side) shows that the positive effect almost triples from 2.8 to 8.1 percent across the period 1990-2015. In the full model with additional controls on the right side, the effect is reduced but remains unmistakable. The effects related to the Liberals are even more revealing. In 1990, the marginal impact of restricting immigrant welfare rights on voting for the Liberals was statistically non-significant in the base model (left side) and even negative in the full model (right side). These results suggest that voters wishing to restrict immigrant welfare rights were unlikely to vote for the Liberals around 1990. In 2001 and onwards, however, the marginal effect of restricting immigrant welfare rights on a vote for the Liberals turns positive in the full model. Consequently, as the Liberals introduced a harsher stand on immigration, they increasingly attracted voters preferring restricted immigrant welfare rights.

[Figure 6 about here] 
The electoral position of the Social Democrats is essentially a 'negative' mirror image of the two right-wing parties. In 1990, interest in restricting immigrant welfare rights had no influence on the likelihood of voting for the Social Democrats. Moreover, in the early 1990s, the confidence intervals for the Social Democrats overlap with the intervals for the DPP and Liberals. In contrast, the impact of restricting immigrant welfare rights on voting for the Social Democrats then becomes negative in sign around the second half of the period. In other words, voters who want restricted immigrant welfare rights have become significantly less likely to support the Social Democrats during the period 1990-2015. Regarding the other center-left party (the Socialist People's Party), no partisan sorting appears - as the negative effect of restricting immigrant welfare rights remains around -1.5 percentage points throughout the period in both model specifications. ${ }^{17}$

Consistent with hypothesis $\left(\mathrm{H}_{3}\right)$, our analyses vindicate the claim that negative views on immigrant welfare rights stimulated partisan realignment in Denmark. The DPP and Liberals have attracted large numbers of voters who want restricted immigrant welfare rights. More generally, the findings in Figure 6 suggest that immigrant welfare rights have been a wedge issue, enabling right-wing parties to attract voters from their main opponent (the Social Democrats). Because the Liberals and DPP managed to reinvent themselves as welfare guardians in the immigration debate, the 'chauvinistic' voters rewarded them, especially since the mid-1990s. ${ }^{18}$

\section{Discussion and Conclusion}


Both Baldwin (1990) and Esping-Andersen (1990) concluded that social solidarity in Scandinavia was unparalleled. Finseraas $(2012,39)$ also found 'no support for the claim that xenophobia undermines support for redistribution`. However, our 25-year study suggests that social solidarity (across income differentials) has weakened. Moreover, some studies suggest that support for restricting immigrant welfare rights is limited among generous welfare states (de Koster, Achterberg \& van der Waal 2012; Koster, Achterberg \& van der Waal 2013; van der Waal, de Koster \& Oorschot 2013). However, in 2015, 60 percent of the electorate disagreed with the statement that immigrants and refugees should enjoy the same right to social assistance as ethnic Danes (see valgprojektet.dk). Thus, welfare chauvinism in Denmark is not occurring among a negligible segment of 'bigots'.

Expanding on our explanatory framework, mass-level explanations cannot stand alone as analyses indicated that individuals' predispositions do not translate into opposition to immigrant welfare rights independently of national politics. Longitudinal analyses indicated that ethnicity coding emerged in the last half of the 1990s when a right-wing coalition brought the immigration-welfare nexus center stage. In effect, our results are inconsistent with Schmidt \& Spies' (2014) conclusion that radical right parties are solely responsible for stimulating fears of immigrants' abuse of social assistance. Our data suggest that radical right parties may be dependent on support from the traditional right-wing parties because they confront relatively stricter legitimacy criteria as indicated by Boss \& van der Brug (2010).

The electoral consequences of immigrant welfare rights need emphasis, as they relate to a long-lasting scholarly interest in the relationship between race/ethnicity issues 
and electoral behavior. As in many other European countries, the Danish case reaffirms that the immigration-welfare nexus tends to strengthen the electoral power of right-wing parties, whereas it weakens support for the traditional social democratic parties (also e.g., de Koster, Achterberg \& van der Waal 2012). In search of a new 'winning formula', these parties face the difficult task of reconciling their support for strong social solidarity (across income differentials) with the realities of disproportionate ethnic representation among social assistance recipients. The task is difficult because their core working class constituencies support social solidarity but remain opposed to generous social assistance offered to non-Western immigrants.

A further contribution of this study concerns the ability of welfare institutions to resist political pressure (see Pierson 1996). In this respect, Brady \& Finnigan (2014) suggest that the USA might be an unusual case in terms of how ethnic diversity shapes certain welfare attitudes and institutions. However, we have shown that some of the American experiences also emerge in an entirely different welfare state; and other studies report that ethnicity coding also occurs in Britain, Canada, Norway, and Sweden (see Bay, Finseraas, \& Pedersen 2013; Ford 2016; Hjorth 2016; Larsen 2011). From this observed invariance, it follows that strong institutionalist claims (see e.g., Crepaz \& Damron 2009) concerning the ability of universal welfare states to prevent ethnicity coding should be read with skepticism. It seems as though political parties - when supported by considerable parts of the electorate - are sometimes powerful enough to delegitimize specific institutional arrangements, which in turn changes their modus operandi (Gilens 1996; Winter 2006). 
The implications of our analyses also relate to the overall impact of ethnicity coding on the universal welfare state. Some may argue that migration and flows of refugees undermine welfare support across the board (Alesina \& Glaesar 2004; Eger 2010; Schmidt-Catran \& Spies 2016). Consistent with Brady \& Finnigan (2014), who warn against too sweeping conjectures, our analyses showed that the impact of perceived ethnic threat on welfare opinions depends on political party messages and the specific scheme referred to (also Winter 2006). Immigration reduces support for welfare schemes being associated with ethnic minority members, whereas it may increase support for welfare schemes that disproportionally benefit native majority members and middle class members in particular (also Jensen 2012).

All studies have weaknesses, including ours. One challenge is to specify the exact mechanisms at the individual-level. Related to our key measure: Exactly how does threat perceptions operate in the mind of the average citizen? Somehow, threat perceptions must relate to important deservingness criteria, such as control (unwillingness to work), identity (not one of us) and reciprocity (has little to offer) (Keskinen, Norocel \& Jørgensen 2016; van Oorschot 2000). However, the balance between these deservingness criteria is an important issue, which can only be established by the use of sophisticated experiments. Moreover, the balance might also depend on how political parties frame immigrant social recipients.

Finally, the analyses have additional weaknesses. First, we cannot test whether electoral pressures governed political party activities in the immigration area. Second, the influence of the media on the political parties remains unsettled. Third, the influence of greater inflows of immigrants also remains unexamined. However, these weaknesses may 
not undermine our top-down model. Expanding on this claim, we agree with Odmalm \& Bale (2015 that political parties do not respond mechanically to the electorate. For instance, some issues may conflict with a party's ideals, while others may be ignored because they cause tensions in a given coalition. Evidently, political parties are voteseeking but this motive does not persistently overrule the motives of policy-seeking or office-seeking (Strøm 1990). Specifically, the Swedish conservative party has not yet accepted the Sweden Democrats, whereas this contrasts with the situation in Denmark. Some scholars conclude that this difference between the Conservative parties has specific historical roots (Wickström 2013). As far as the media are concerned, our approach draws on Bennett (1990) who proposes that the media agenda often reproduces political party messages. By implication, if politicians ignore specific issues and frames, these will also be ignored by the media. Finally, does the attention of political parties to immigration issues just reflect that the inclusion of this group proved more difficult than expected? Certainly, the integration task is more challenging today than it was twenty years ago. Yet the task of defining objective realities is a key feature of politics, but it is predominantly elites who frame realities. In Denmark, right-wing politicians have focused on immigration as a threat for about twenty years, whereas this frame was absent in some countries like Sweden or Germany (until radical right parties had their breakthrough). In short, politicians do not create citizen's predispositions but they help in translating these into specific (welfare) opinions.

\section{Notes}


1 'Immigrants' refer primarily to foreigners of non-Western descent. Non-Western immigrants are persons who were born outside the EU/EFTA, Australia, Canada, New Zealand, or the USA.

${ }^{2}$ Jensen (2012) concludes that labor market related (e.g., social assistance) and life-cycle related welfare programs (e.g., pensions) differ in terms of popularity. There is an inbuilt middle class bias in the welfare state as life-cycle programs are the most popular. This observation is not inconsistent with our argument as we believe that the presence of non-Western immigrants only accentuates this bias because of their lower labor market participation.

${ }^{3}$ According to UN statistics (2017), Denmark does not figure among the twenty largest nations of destination of international migrants.

${ }^{4}$ We excluded 'don't know' responses and refusals for both attitudinal and demographic items.

${ }^{5}$ Schmidt and Spies (2014) applied a single item addressing attitudes toward measures meant to reduce differences in income levels. However, this single distribution item does not allow a differentiated view on social redistribution. One the one hand, those scoring high on perceived ethnic out-group threat may oppose policies that redistribute across ethnic divisions. On the other, the very same persons may support policies enabling income distribution within the native majority group.

${ }^{6}$ Unfortunately, self-reported income in the DNES data sets has numerous missing cases, and different measurements were used across this 25 -year period. Moreover, we arrive at substantially similar results when rerunning the models with a reduced data set using a standardized income variable (available on request). These models, however, cause a loss of more than 1,000 observations. These are the reasons for not including income as a control.

${ }^{7}$ See the online appendix for more details on the political parties (p. 31).

${ }^{8}$ The controls applied in these models are similar to the models examining spending opinions.

${ }^{9}$ According to the Comparative Manifesto Project Data, the correlation between election year and the DPP's position on immigration is 0.82 . The correlation between election year and the Liberals' position on immigration is 0.45 . We arrive at substantially similar conclusions when replacing year with the positions of the Liberals or the DPP on immigration. See Figure B1 in the online appendix for a comparison. ${ }^{10}$ All of the marginal effects below were calculated for a male voter, aged 30-39, from the lower salariat, with a medium level of education and a union membership card. All other primarily interval-scaled control variables were kept at their medians or means.

${ }^{11}$ Considering the small number of observations for the category 'too high', we reran the model as a binary logit specification after having merged 'too high' and 'fair'. The results do not differ from the conclusion reported (see Figures $\mathrm{C} 1$ and $\mathrm{C} 2$ in the online appendix).

${ }^{12}$ As a robustness check, the online appendix shows the results when the dependent measures of support were specified as dummy variables (Figures D1-D2). The online appendix also shows the results with different model specifications - and the substantial conclusion is insensitive toward these (see Figures D3D4). 
${ }^{13}$ The full models of this analysis appear in Table D3 in the online appendix (also Table D4).

${ }^{14}$ We explored some of these in detail using marginal effects analysis - see Figure D1 in the online appendix, while robustness analyses are reported in Table B4, Tables C1-C4 and Figures C3-C4.

${ }^{15}$ We reran the baseline models with additional factors at the context level. As additional controls, we added polarization on economic issues among the major parties, the unemployment rate in an election year, the share of seniors, the number of non-Western immigrants, and the voters' issue agenda. These controls did not affect our main conclusions.

${ }^{16}$ We reran the same models with different statistical specifications. These models generate substantially similar conclusions (see Table D5 and Figure D5 in the online appendix for a comparison of the coefficients including the marginal effects derived from logit and probit specifications). We also reach a similar conclusion if party cues replace elections year as moderators (not reported).

${ }^{17}$ For the remaining parties, we found a similar negative and increasing effect of restricting immigrant welfare rights on voting for the radical left (The Red-Green Alliance), whereas smaller center-right parties (e.g., the Liberal Alliance) attract some voters from the category supporting restricted immigrant welfare rights (see Figure E1 in the online appendix for analysis of the four minor parties).

${ }^{18}$ We examined whether former Social Democratic voters were likely to switch to the center-right parties when using the vote recall item. These supplementary analyses support the results referred to above, and they are reported in Figure D6 in the online appendix. 


\section{References}

Ai, C. \& Norton, E. C. 2003. 'Interaction Terms in Logit and Probit Models', Economic Letters, 80, 123-29.

Alesina, A. \& Glaeser, E. L. 2004. Fighting Poverty in the US and Europe: A World of Difference. Oxford: Oxford University Press.

Arndt, C. 2016. 'Issue Evolution and Partisan Polarization in a European Multiparty System: Elite and Mass Repositioning in Denmark 1968-2011', European Union Politics, 17(4), 660-682.

Baldwin, P. 1990. The Politics of Social Solidarity: Class Bases of the European Welfare State, 1875-1975. Cambridge: Cambridge University Press.

Bale, T. 2003. 'Cinderella and Her Ugly Sisters: The Mainstream and Extreme Right in Europe's Bipolarising Party Systems', West European Politics, 26(3), 67-90.

Bay, A-H., Finseraas, H \& Pedersen, A. W. 2013. 'Welfare Dualism in Two Scandinavian Welfare States: Public Opinion and Party Politics', West European Politics, 36(1), 199-220.

Bennett, W. L. 1990. 'Toward a Theory of Press-State Relations in the United States', Journal of Communication, 40(2), 103-25.

Boss, L. \& van der Brug, W. 2010. 'Public Images of Anti-Immigration Parties: Perceptions of Legitimacy and Effectiveness', Party Politics, 16(6), 777-99.

Brader, T., Valentino, N. A \& Suhay, E. 2008. 'What Triggers Public Opposition to Immigration? Anxiety, Group Cues, and Immigration', American Journal of Political Science, 52(4), 959-78.

Brady, D. \& Finnigan, R. 2014. 'Does Immigration Undermine Public Support for Social Policy?', American Sociological Review, 79(1), 27-42.

Brochmann, G. \& Hagelund, A. 2011. 'Migrants in the Scandinavian Welfare State', Nordic Journal of Migration Research, 1(1), 13-24.

Crepaz, M. M. L. \& Damron, R. 2009. 'Constructing Tolerance. How the Welfare State Shapes Attitudes about Immigrants’, Comparative Political Studies, 42(3), 437-63.

De Koster, W., Achterberg, P. \& van der Waal, J. 2012. 'The New Right and the Welfare State: The Electoral Relevance of Welfare Chauvinism and Welfare Populism in the Netherlands', International Political Science Review, 34(1), 3-30.

Eger, M. 2010. 'Even in Sweden: The Effect of Immigration on Support for Welfare State Spending', European Sociological Review, 26(2), 203-17. 
Eger, M. \& Valdez, S. 2015. 'Neo-Nationalism in Western Europe', European Sociological Review, 31(1), 115-130.

Esping-Andersen, G. 1990. The Three Worlds of Welfare Capitalism. Oxford: Polity Press.

Finseraas, H. 2012. 'Anti-immigration Attitudes, Support for Redistribution and Party Choice in Europe', in Kvist, J., Fritzell, J., Hvinden, B. \& Kangas, O., eds, Changing Social Equality. Bristol. The Policy Press.

Ford, R. 2016. 'Who Should We Help? An Experimental Test of Discrimination in the British Welfare State', Political Studies, 64(3), 630-50.

Gilens, M. 1996. 'Race Coding' and White Opposition to Welfare', American Political Science Review, 90(3), 593-604.

Green-Pedersen, C. 2011. Partier i nye tider. Aarhus: Aarhus University Press.

Harell, A., Soroka, S. \& Ladner, K. 2014. 'Public Opinion, Prejudice and the Racialization of Welfare in Canada', Ethnic and Racial Studies, 37(14), 2580-97.

Hillygus, D. S. \& Shields., T. G. 2008. The Persuadable Voter: Wedge Issues in Presidential Campaigns. Princeton: Princeton University Press.

Hjorth, F. 2016. 'Who Benefits? Welfare Chauvinism and National Stereotypes', European Union Politics, 17(1), 3-24.

Hurwitz, J. \& Peffley, M. 2005. 'Playing the Race Card in the Post-Willie Horton Era', Public Opinion Quarterly, 69(1), 99-112.

Jensen, C. 2012. 'Labour Market- versus Life Course-Related Social Policies:

Understanding Cross-Program Differences', Journal of European Public Policy, 19(2), 275-291.

Jønsson, H. V \& Petersen, K. 2013. 'From a "Social Problem" to a "Cultural Challenge" to the National Welfare State: Immigration and Integration Debates in Denmark 19702011', in Suszycki, A. M. \& Karolewski, I. P., eds, Citizenship and Identity in the Welfare State. Baden-Baden: Nomos.

Keskinen, S., Norocel, O.C. \& Jørgensen, M. B. 2016. 'The Politics and Policies of Welfare Chauvinism Under the Economic Crisis', Critical Social Policy, 36(3), 321-329.

Larsen, C. A. 2011. 'Ethnic Heterogeneity and Public Support for Welfare: Is the American Experience Replicated in Britain, Sweden, and Denmark?', Scandinavian Political Studies, 34(4), 332-53. 
Luskin, R. \& Bollock, J. G. 2011. “'Don't Know' Means 'Don’t Know': DK Responses and the Public's Level of Political Knowledge', Journal of Politics, 73(2), 547-57.

Odmalm, P. \& Bale, T. 2015. 'Immigration into the Mainstream: Conflicting Ideological Streams, Strategic Reasoning and Party Competition', Acta Politica, 50(4), 365-78.

OECD 2016. 'OECD Development Co-operation Peer Reviews: Denmark 2016, OECD Development Cooperation Peer Reviews', Paris OECD Publishing. http://dx.doi.org/10.1787/9789264259362-en

Pierson, P. 1996. 'The New Politics of the Welfare State', World Politics, 48(2), 143-79.

Schmidt, A. W. \& Spies, D. C. 2014. 'Do Parties “Playing the Race Card" Undermine Natives' Support for Redistribution? Evidence from Europe', Comparative Political Studies, 47(4), 519-49.

Schmidt-Cathran, A. W. \& Spies, D. C. 2016. 'Immigration and Welfare Support in Germany’, American Sociological Review, 81(2), 242-61.

Sniderman, P. M. \& Hagendoorn, L. 2007. When Ways of Life Collide: Multiculturalism and Its Discontent in the Netherlands. Princeton: Princeton University Press.

Soroka, S. N. 2006. 'Good News and Bad News: Asymmetric Responses to Economic Information', Journal of Politics, 68(2), 372-85.

Strøm, K. 1990. 'A Behavioral Theory of Competitive Political Parties', American Journal of Political Science, 34(2), 565-98.

Thomsen, J. P. F. 2006. Konflikten om de nye danskere. København: Akademisk Forlag.

UN 2017. 'International Migration Report 2017'. New York: United Nations (available at: www.un.org).

Van Oorschot, W. 2000. 'Who Should Get What, and Why? On Deservingness Criteria and the Conditionality of Solidarity Among the Public', Policy \& Politics, 28(1), 33-48.

Van der Waal, J., De Koster \& Van Ooschot, W. 2013. 'Three Worlds of Welfare Chauvinism? How Welfare Regimes Affect Support for Distributing Welfare to Immigrants in Europe', Journal of Comparative Policy Analysis, 15(2), 164-181.

Wickström, M. 2013. 'The Difference White Ethnics Made: The Multiculturalist Turn of Sweden in Comparison to the Cases of Canada and Denmark', in Jønsson, H. V., Onasch, E., Pellander, S. \& Wickström, M., eds, Migrations and Welfare States Policies, Discourses and Institutions. Helsinki: Bookwell. 
Winter, N. J. G. 2006. 'Beyond Welfare: Framing and the Racialization of White Opinion on Social Security', American Journal of Political Science, 50(2), 400-20.

Wright, M. \& Bloemraad, I. 2012. 'Is There a Trade-off between Multiculturalism and Socio-Political Integration? Policy Regimes and Immigrant Incorporation in Comparative Perspective', Perspectives on Politics, 10(1), 77-95.

Zaller, J. R. 1992. The Nature and Origins of Mass Opinion. Cambridge: Cambridge University Press. 


\section{Supporting Information}

Additional Supporting Information may be found online in the supporting information tab for this article. 
Figure 1: Recipients of the People's Pension and Social Assistance, by Ethnic Background, 1997-2015 (percent)

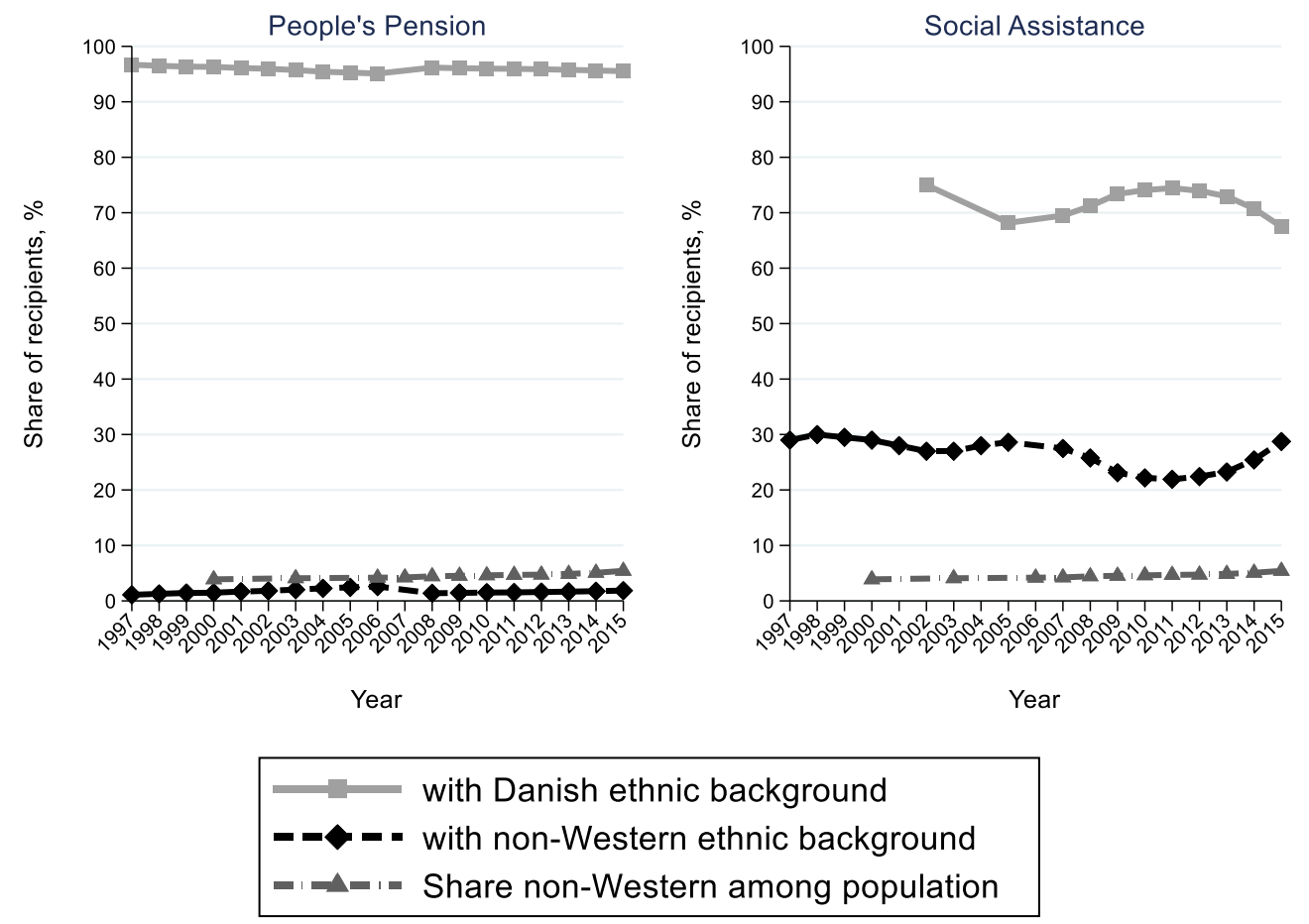

Source: Statistics Denmark and various sources (see the online appendix for detailed information and specifications). 
Figure 2: Policy Positions of Danish Political Parties on Immigration Issues, 1968-2011

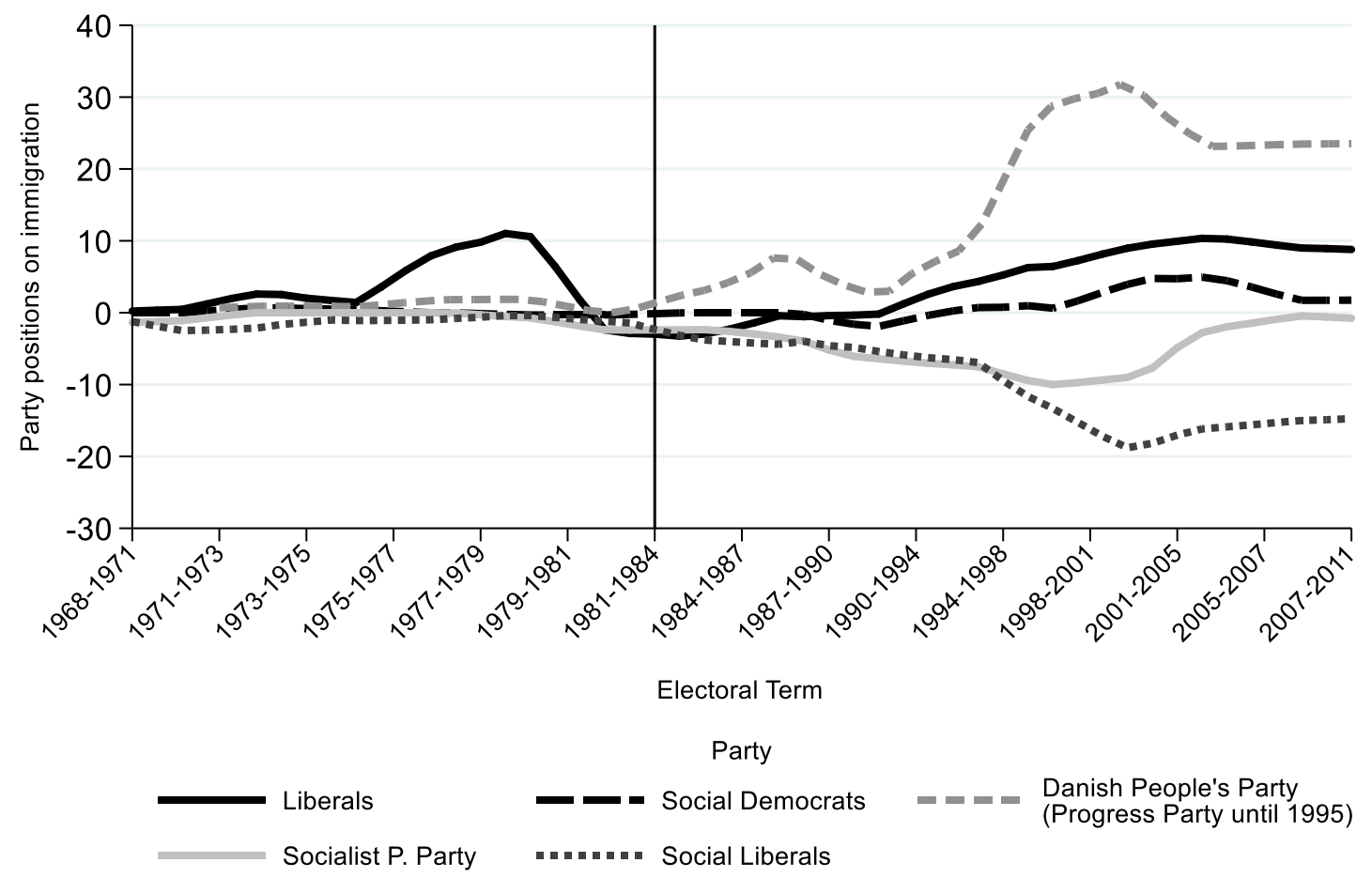

Note: Positive values indicate restrictive positions on immigration/multiculturalism/national way of life, whereas negative values indicate liberal positions on immigration/multiculturalism/national way of life for the five political parties. Lines were smoothed.

Source: Own calculations based on Comparative Manifesto Project data ((per109 + per601 + per608) (per107 + per602 + per607)). 
Table 1: Perceived Ethnic Threat and Opinion on Spending on the People's Pension in Election Years, 1990-2015

\begin{tabular}{|c|c|c|c|c|c|}
\hline & $\begin{array}{l}\text { M1 without } \\
\text { interaction }\end{array}$ & $\begin{array}{l}\text { M2 with } \\
\text { interaction }\end{array}$ & $\begin{array}{c}\text { M3 with } \\
\text { additional } \\
\text { demographics }\end{array}$ & $\begin{array}{c}\text { M4 with } \\
\text { egalitarianism }\end{array}$ & $\begin{array}{c}\text { M5 with } \\
\text { egalitarianism } \\
\text { and PI }\end{array}$ \\
\hline Perceived ethnic threat & $\begin{array}{c}0.176^{* * * *} \\
(0.015)\end{array}$ & $\begin{array}{c}-13.512 * * * \\
(3.835)\end{array}$ & $\begin{array}{c}-12.631 * * \\
(3.841)\end{array}$ & $\begin{array}{c}-14.116 * * * \\
(3.896)\end{array}$ & $\begin{array}{c}-11.088^{*} \\
(4.524)\end{array}$ \\
\hline Year & $\begin{array}{c}-0.033 * * * \\
(0.004)\end{array}$ & $\begin{array}{c}-0.053 * * * \\
(0.007)\end{array}$ & $\begin{array}{c}-0.055^{* * * *} \\
(0.007)\end{array}$ & $\begin{array}{c}-0.055 * * * \\
(0.007)\end{array}$ & $\begin{array}{c}-0.041 * * * \\
(0.008)\end{array}$ \\
\hline $\begin{array}{l}\text { Perceived ethnic threat } \times \\
\text { year }\end{array}$ & & $\begin{array}{c}0.007 * * * \\
(0.002)\end{array}$ & $\begin{array}{c}0.006 * * * \\
(0.002)\end{array}$ & $\begin{array}{c}0.007 * * * \\
(0.002)\end{array}$ & $\begin{array}{l}0.006^{*} \\
(0.002)\end{array}$ \\
\hline Cut point 1 & $\begin{array}{c}69.847 * * * \\
(7.101)\end{array}$ & $\begin{array}{c}109.892 * * * \\
(13.284)\end{array}$ & $\begin{array}{c}113.648 * * * \\
(13.307)\end{array}$ & $\begin{array}{c}115.636 * * * \\
(13.449)\end{array}$ & $\begin{array}{c}86.141 * * * \\
(16.471)\end{array}$ \\
\hline Cut point 2 & $\begin{array}{c}65.275^{* * * *} \\
(7.102)\end{array}$ & $\begin{array}{c}105.312 * * * \\
(13.283)\end{array}$ & $\begin{array}{c}109.064 * * * \\
(13.305)\end{array}$ & $\begin{array}{c}111.014 * * * \\
(13.448)\end{array}$ & $\begin{array}{c}81.484 * * * \\
(16.471)\end{array}$ \\
\hline $\begin{array}{l}\mathrm{N} \\
-2 \text { Loglikelihood }\end{array}$ & $\begin{array}{c}11,643 \\
-8276.925\end{array}$ & $\begin{array}{c}11,643 \\
-8269.375\end{array}$ & $\begin{array}{c}11,642 \\
-8258.203\end{array}$ & $\begin{array}{c}11,471 \\
-8063.118\end{array}$ & $\begin{array}{c}10,567 \\
-7391.485\end{array}$ \\
\hline Nagelkerke $\mathrm{R}^{2}$ & 12.0 & 12.1 & 12.3 & 13.8 & 14.8 \\
\hline BIC & 16729.737 & 16725.999 & 16722.378 & 16322.536 & 15060.934 \\
\hline
\end{tabular}

Figure 3: The Effect of Perceived Ethnic Threat on Support for the People's Pension in Election Years, 1990-2015

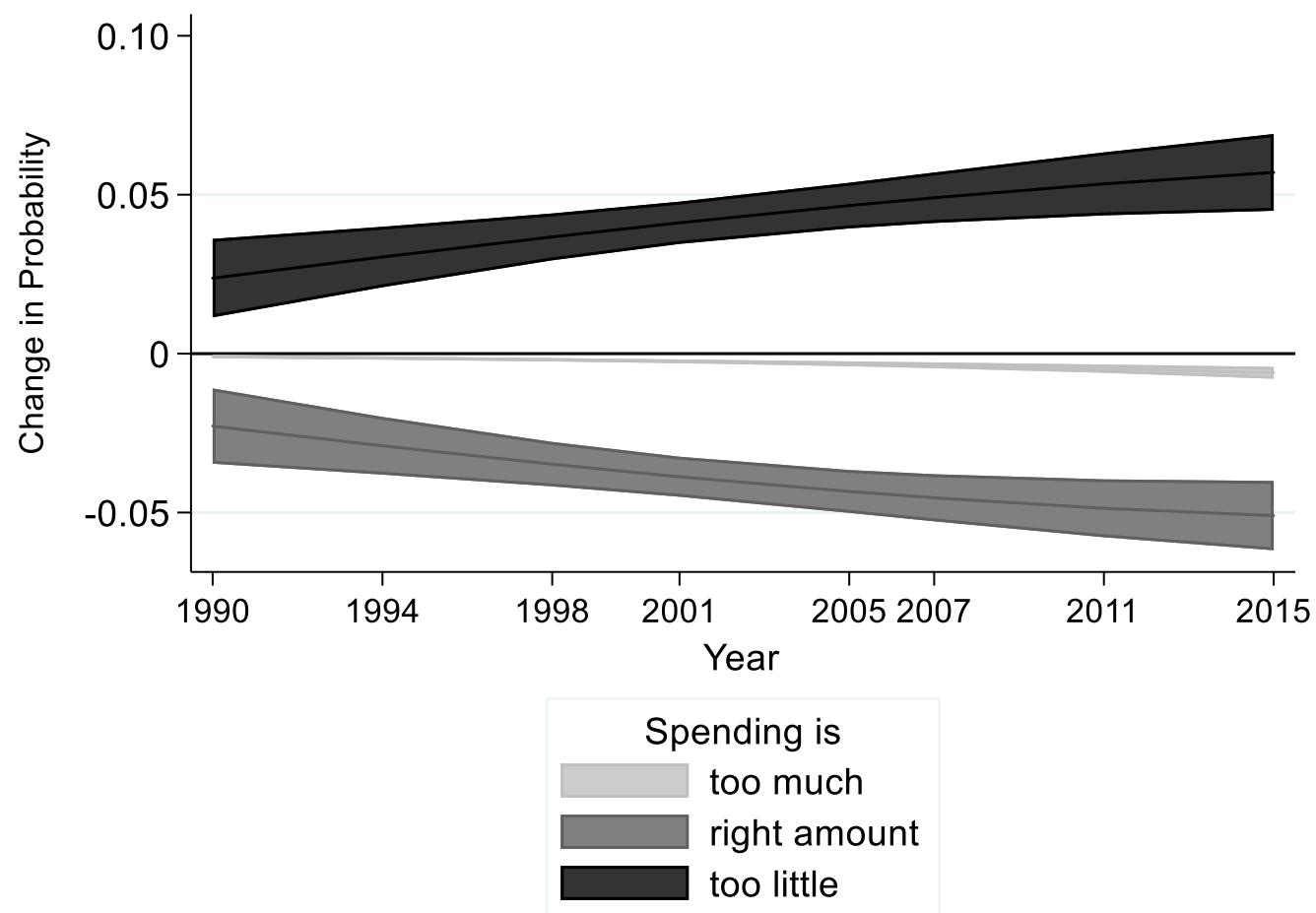


Note: Marginal effects of perceived ethnic threat, based on estimates from M2 in Table 1. Y-axis shows change (greater/less) in probability of agreeing 'too high', 'fair', or 'too low' at each election. Shaded regions indicate 95percent confidence intervals.

Table 2: The Effect of Perceived Ethnic Threat on Support for Spending on Social Assistance Across Election Years, 1990-2015

\begin{tabular}{|c|c|c|c|c|c|}
\hline & $\begin{array}{l}\text { M1 without } \\
\text { interaction }\end{array}$ & $\begin{array}{l}\text { M2 with } \\
\text { interaction }\end{array}$ & $\begin{array}{c}\text { M3 with } \\
\text { additional } \\
\text { demographics }\end{array}$ & $\begin{array}{c}\text { M4 with } \\
\text { egalitarianism }\end{array}$ & $\begin{array}{c}\text { M5 with } \\
\text { egalitarianism } \\
\text { and PI }\end{array}$ \\
\hline Perceived ethnic threat & $\begin{array}{c}-0.191 * * * \\
(0.015)\end{array}$ & $\begin{array}{c}2.962 \\
(4.145)\end{array}$ & $\begin{array}{c}3.004 \\
(4.148)\end{array}$ & $\begin{array}{c}1.515 \\
(4.189)\end{array}$ & $\begin{array}{l}9.007+ \\
(4.766)\end{array}$ \\
\hline Year & $\begin{array}{c}0.025 * * * \\
(0.004)\end{array}$ & $\begin{array}{c}0.030 * * * \\
(0.007)\end{array}$ & $\begin{array}{c}0.029 * * * \\
(0.007)\end{array}$ & $\begin{array}{c}0.028 * * * \\
(0.007)\end{array}$ & $\begin{array}{l}0.045 * * * \\
(0.008)\end{array}$ \\
\hline $\begin{array}{l}\text { Perceived ethnic threat } \times \\
\text { year }\end{array}$ & & $\begin{array}{l}-0.002 \\
(0.002)\end{array}$ & $\begin{array}{l}-0.002 \\
(0.002)\end{array}$ & $\begin{array}{l}-0.001 \\
(0.002)\end{array}$ & $\begin{array}{c}-0.005+ \\
(0.002)\end{array}$ \\
\hline Cut point 1 & $\begin{array}{l}-48.263 * * * \\
(7.634)\end{array}$ & $\begin{array}{l}-57.212 * * * \\
(13.385)\end{array}$ & $\begin{array}{l}-54.635 * * * \\
(13.453)\end{array}$ & $\begin{array}{l}-53.758 * * * \\
(13.456)\end{array}$ & $\begin{array}{l}-87.624 * * * \\
\quad(16.026)\end{array}$ \\
\hline Cut point 2 & $\begin{array}{c}-51.551 * * * \\
(7.637)\end{array}$ & $\begin{array}{c}-60.500 * * * \\
(13.386)\end{array}$ & $\begin{array}{c}-57.932 * * * \\
(13.454)\end{array}$ & $\begin{array}{c}-57.094 * * * \\
(13.458)\end{array}$ & $\begin{array}{c}-91.017 * * * \\
(16.028)\end{array}$ \\
\hline $\mathrm{N}$ & 11,040 & 11,040 & 11,039 & 10,901 & 10,110 \\
\hline -2Loglikelihood & -9323.942 & -9323.602 & -9305.494 & -9114.769 & -8361.712 \\
\hline Nagelkerke $\mathrm{R}^{2}$ & 22.5 & 22.5 & 22.8 & 24.0 & 24.7 \\
\hline $\mathrm{BIC}$ & 18824.76 & 18333.389 & 18815.790 & 18424.767 & 17000.062 \\
\hline
\end{tabular}

Note: Entries are ordered logit coefficients with robust standard errors in parentheses. Full models appear in Table D2 in the online appendix. (PI = party identification) $* * * p<0.001, * * p<0.01, * p<0.05,+p<0.1$ (two-tailed).

Source: DNES 1990-2015. 
Figure 4: The Effect of Perceived Ethnic Threat on Support for Social Assistance Across Election Years, 1990-2015

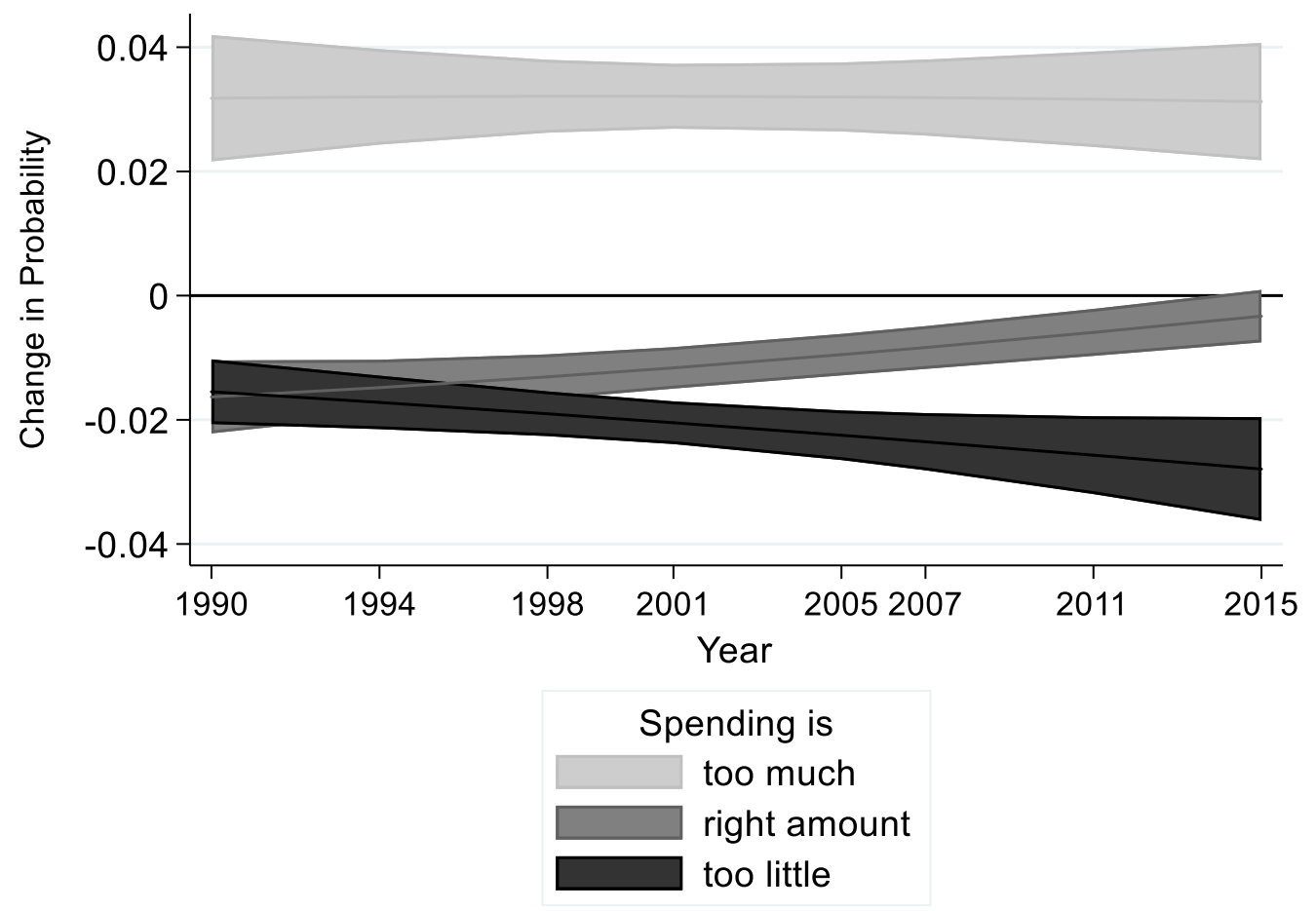

Note: Marginal effects of perceived ethnic threat based on M2 from Table 2. Y-axis shows change (greater/less) in probability of agreeing 'too high', 'fair', or 'too low' at each election. Shaded regions indicate 95 -percent confidence intervals. 
Figure 5: The Effect of Perceived Threat of Muslim Countries on Support for Two Welfare Schemes Across Election Years, 1990-2015
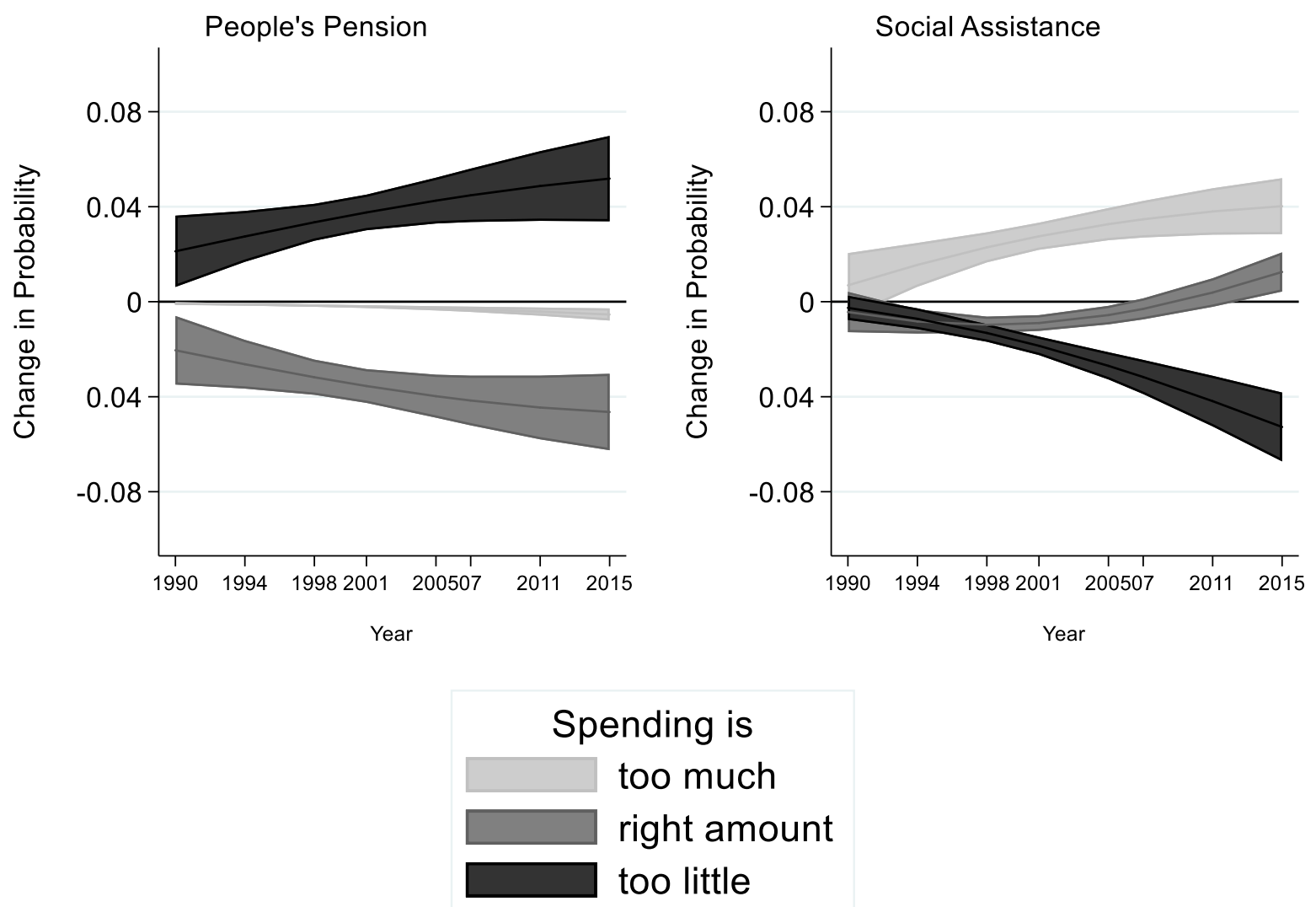

Note: Marginal effects derived from base models in Table D3 in the online appendix $(\mathrm{N}=9,747$ and 9,202). The model setup follows model M2 from Tables 1 and 2 and uses the Muslim threat instead of the perceived ethnic threat variable. Y-axis shows change (greater/less) in probability of agreeing 'too high', 'fair', or 'too low' at each election. Shaded regions indicate 95-percent confidence intervals. 
Table 3: Opinions on Social Assistance Spending and Immigrant Welfare Rights (row percent)

\begin{tabular}{llllll|l}
\hline \hline & \multicolumn{5}{c}{ Immigrants same welfare rights as Danes } \\
\cline { 2 - 7 } $\begin{array}{l}\text { Spending on } \\
\text { social assistance }\end{array}$ & $\begin{array}{l}\text { Totally } \\
\text { agree }\end{array}$ & $\begin{array}{l}\text { Partly } \\
\text { agree }\end{array}$ & Neither/nor & $\begin{array}{l}\text { Partly } \\
\text { disagree }\end{array}$ & $\begin{array}{l}\text { Totally } \\
\text { disagree }\end{array}$ & Total \\
is: & & & & & & \\
Too high & 4.24 & 9.90 & 11.24 & 28.95 & 45.67 & 100.00 \\
Fair & 9.57 & 19.27 & 17.69 & 30.36 & 23.12 & 100.00 \\
Too low & 24.45 & 25.87 & 15.62 & 15.26 & 18.81 & 100.00 \\
\hline Total & 11.01 & 18.36 & 15.90 & 27.39 & 27.34 & 100.00 \\
\hline
\end{tabular}

Note: $\mathrm{N}=12,817$.

Source: DNES 1990-2015.

Figure 6: The Effect of Opposition to Immigrant Welfare Rights on Vote Choice, 19902015
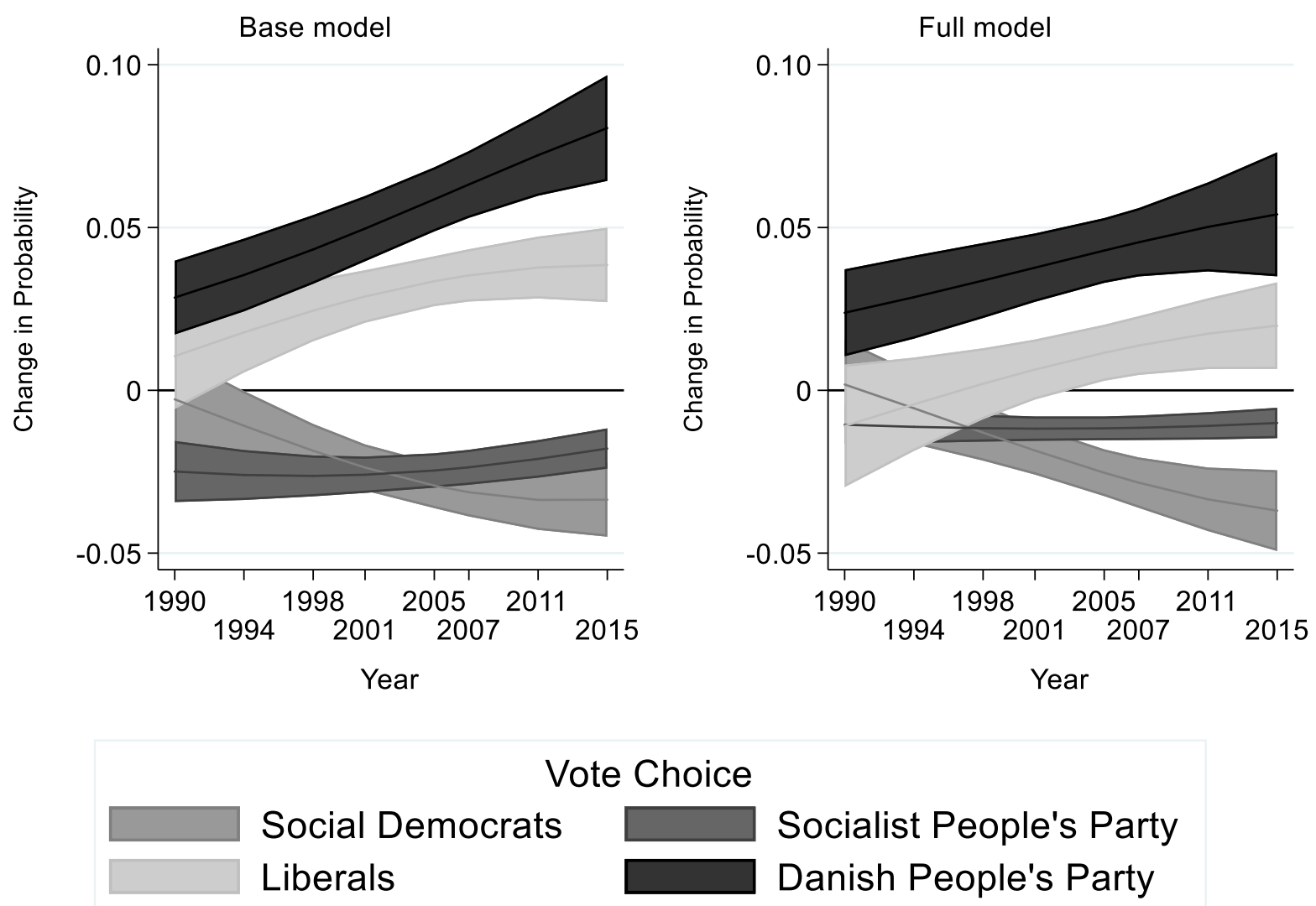

Note: Multinomial logistic regression models $(\mathrm{N}=37,284$ for base model and $\mathrm{N}=36,468$ for full model). Lines show marginal effects of restricting immigrant welfare rights on vote choice across election years. The panel on the left shows the base model, whereas the one on the right shows the full model. See Table E1 in the online appendix for regression tables and further details on model specification. Y-axis shows (greater/less) change in probability of voting on four specific political parties. Shaded regions indicate 95percent confidence intervals.

Source: DNES 1990-2015. 